\title{
URBAN FORMATION, BLOCK TRANSFORMATION AND PERIMETER BLOCK INNER SPACES IN MEXICAN HISTORICAL NEIGHBORHOOD ANALCO, DURANGO CITY
}

Towards an alternative strategy for rehabilitation of historical suburban district positioned as a buffer zone of a world heritage

\author{
メキシコの歴史的地区・ドゥランゴ市アナルコ地区の形成と街区内空地 \\ 世界遺産のバッファゾーンに位置づけられた歴史的郊外の再生をめざして
}

\author{
Hassibi Alejandra MORA PEREZ* and Yuichi FUKUKAWA** \\ モラペレスハシビアレハンドラ，福川裕一
}

\begin{abstract}
The Analco neighborhood is located in the buffer zone of the newly regenerated historic centre of the city of Durango. It has suffered from deterioration and an indifference that became more evident when the work for regenerating the core zone of the historical centre started. In order to be able to propose an efficient strategy for rehabilitation, it is necessary to research an area that has not been thoroughly studied previously. Based on the results of different analysis made of the neighborhood, it was possible to know that the Analco neighborhood started as an independent Indigenous town that later was absorbed by the city of Durango, and due to the activities performed there the blocks in the neighborhood and the historical centre of Durango are different: the blocks shapes and sizes are influenced by the natural irregularities of the land, the combination of the block sizes, plot divisions and architecture, which gave as a result the existence of perimeter block inner spaces. Furthermore, the family ties of the owners of the plots in the neighborhood could be a crucial factor for the future use of those spaces.
\end{abstract}

Keywords: Regeneration, Typology, Perimeter block inner space, Historical area, Buffer zone 再生, 類型化, 街区内空地, 歴史的地区, バッファゾーン

\section{Introduction}

Durango is a colonial Spanish-American city located in the north part of Mexico. This city never went through an exhaustive regeneration of its historical areas, and it was only recently that its government started investing all its time and efforts into rehabilitating the core zone of the city's Historic Centre (HC), in order to inscribe it in 2010 as a part of the Silver Route, a World Heritage Site ${ }^{\mathrm{i})}$. The historical neighborhood of Analco is part of its buffer zone and unlike the core zone it has not had any strong regeneration. This fact exposed the differences between the neglected Analco neighborhood and the newly rehabilitated core zone of the HC. The blocks of this neighborhood have particular characteristics that, with the passage of time, generated the existence of perimeter blocks with considerable inner spaces that in some cases, without any planning involved, have not been used in the most ideal way.

The topic of regeneration of historical areas in Spanish-American cities is a subject that has been previously researched however almost none of the research focusses on the use of neglected perimeter block inner spaces (PBIS) as a means for rehabilitation. Some researchers argue that due to the lack of local examples of rehabilitation of Spanish-American cities, the regeneration of their $\mathrm{HC}$ was based on the emulation of successful examples in other countries ${ }^{1)}$, while others say that their rehabilitation should offer spaces for the design of projects for the cooperation between government and people ${ }^{2)}$. On the other hand, local researchers tackle the loss of historical patrimony by the reinterpretation of common architectural
* Ph. D. Candidate, Graduate School of Engineering, Division of Architecture and Urban Science, Chiba University, M. Eng.

** Prof., Graduate School of Engineering, Division of Architecture and Urban Science, Chiba University, Dr. Eng.
千葉大学大学院工学研究科建築・都市科学専攻 博士後期課程 $\cdot$ 修士 (工学)

千葉大学大学院工学研究科建築・都市科学専攻 教授・工博 (工学) 
elements and the negotiation between the parts involved in the preservation and the owners ${ }^{3}$. In addition, Angelo and Deguchi $\left.{ }^{4}\right)$ concerned about the establishment of inner-city slums in another Spanish American city, focused on the typology and uses of the traditional house as well as the analysis of its social fabric.

The purpose of this research is to better understand the formation and evolution of the urban fabric of the Analco neighborhood as well as the analysis of its blocks, plot division and building typology. It investigates how the combination of these factors gave rise to the natural formation of the PBIS which represent a new rehabilitation method for this area through their regeneration.

\section{Methodology and current state of the study area}

The present research is divided into three parts. The first part, concerning the historical context of the Analco Indigenous town, relies on literature survey. The second part, related to the urban formation of Analco and the city plan of 1860, was based in the analysis and comparison of different historical plans of the city of Durango and the special analysis of the 1860 plan of the city of Durango. The third part, related to the PBIS, block analysis and building typology, is based on the information from several governmental offices ii) and from a field survey made by the author in the months of March and April of 2011.

The boundaries of the $\mathrm{HC}$ are defined to the north by Felipe Pescador Avenue, to the south by Ocampo Street, to the east by Miguel de Cervantes Saavedra Street, and to the west by Dolores del Rio Boulevard. ${ }^{5}$ ) The current limits of the HC differ from the ones established in 1982 $2^{\mathrm{iii} i}$, as it only includes ten blocks from the Analco neighborhood. These ten blocks, and the ones included in the later extension of the protected area, constitute the totality of the twenty-five blocks considered for this study (Fig.1).

By 2000 the total population of Analco was 4,767 people and there were 1,220 inhabited houses in the Analco neighborhood. In comparison, in the same year the total population in the $\mathrm{HC}$ of Durango was 22,972 people with 6,362 total dwellings iv). The lack of other modern detailed records make very difficult to know whether the population of the area is decreasing, as the neighbors of Analco say, or how many houses have fallen into disrepair and disuse.

In order to have a better idea of the state of degradation of the neighborhood, a walk recognition made of the zone by the author in March of 2011 indicated an average decay of the area of approximately $24.25 \%$, consisting primarily of houses that have their facades in a bad state and fallen down houses. It is difficult to know which houses are empty, since its bad state is not enough to determine that.

3. Historical context: from Indigenous town to neighborhood of Durango

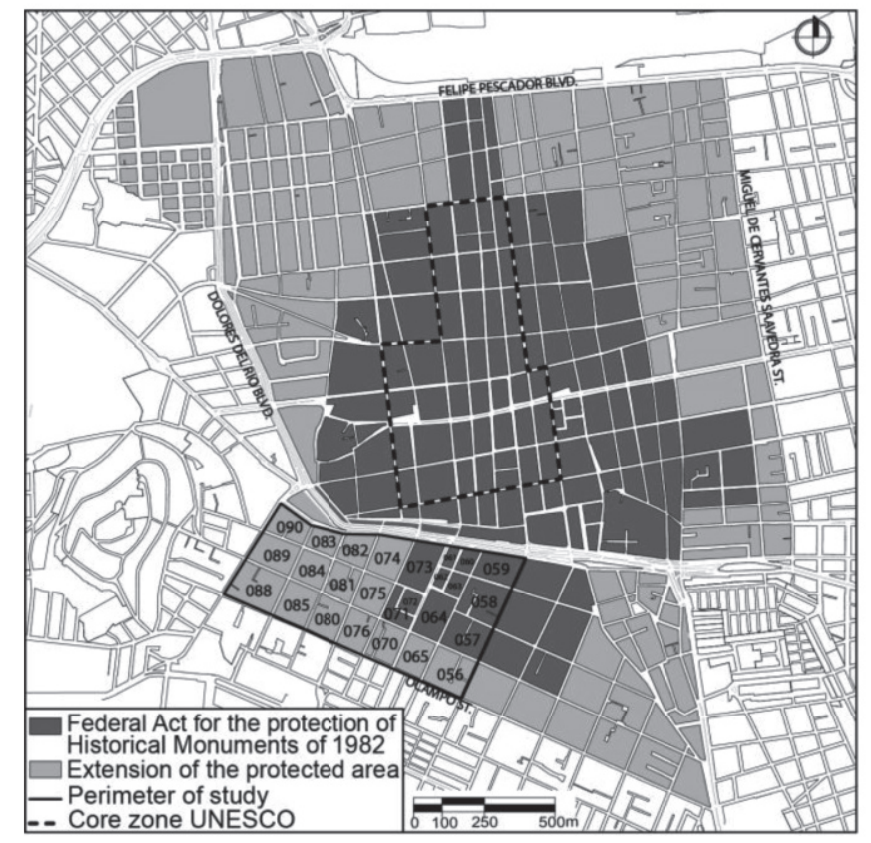

Fig.1 Changes in the limits of the $\mathrm{HC}$ of Durango

The city of Durango was founded and laid out in 1563 in the then Province of Nueva Vizcaya ${ }^{5}$. Alonso de Pacheco was in charge of establishing the village of Durango, in the flat lands of Guadiana Valley ${ }^{6}$ ) and approximately eight years before the San Juan Bautista de Analco Mission was founded by Franciscan friars in the same valley. The mission's main activity was the evangelization of the Tepehuan Indians and other native groups that lived around that area, as laid out by the Laws of Indies ${ }^{7}$.See ${ }^{v}$. San Vicente Creek was a stream of water that separated the Indigenous town and the Spanish Village of Durango ${ }^{\mathrm{vi})}$.

At the beginning of the 17th century the Village of Durango had no more than fifty Spaniards and eighty people of African descent and mulattos for their service. Among the Indigenous towns, the biggest was Analco, with approximately fifty married people. By 1616, Analco's local population was extremely diminished due to rebellions and epidemics ${ }^{8}$. During the 17th century, the town of San Juan Bautista de Analco had a stable population and at the mid 18th century, the growth of the population in the town became accentuated, following the same tendency of the village of Durango. In 1761, there were 610 people and by 1778 there were 777 . By the end of 18th century a more formal parish was establishedvi), replacing the old Franciscan chapel. As Analco grew, Durango's need to keep constant communication with Analco increased. Due to the periodic rise of the water level of San Vicente Creek, in 1795, a stone bridge that crossed over the creek was built, replacing the previous wooden bridge ${ }^{8)}$.

In the Independent Era of Mexico, the complete incorporation Analco and Durango became inevitable. In 1826, without success, the congress of the State of Durango ordered the town of Analco 


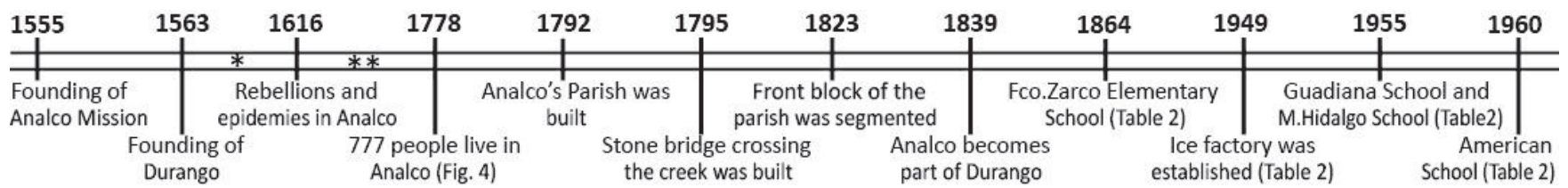

Fig. 2 Timetable of important events of the town of Analco. * 50 married Indigenous people in Analco. ** Steady growth of population

in Durango and Analco.

Table 1 Population of the city of Durango from 1777 to $2010^{\text {viii) }}$

\begin{tabular}{|c|c|c|c|}
\hline Year & Population & Year & Population \\
\hline 1777 & 6,590 & 1910 & 31,763 \\
\hline 1785 & 8,000 & 1921 & 39,091 \\
\hline 1790 & 10,891 & 1930 & 35,330 \\
\hline 1803 & 12,000 & 1940 & 33,412 \\
\hline 1805 & 14,000 & 1950 & 59,496 \\
\hline 1849 & 15,211 & 1960 & 97,305 \\
\hline 1855 & 16,060 & 1970 & 150,541 \\
\hline 1859 & 17,500 & 1990 & 348,036 \\
\hline 1862 & 16,014 & 1995 & 397,687 \\
\hline 1869 & 12,000 & 2000 & 427,135 \\
\hline 1893 & 24,800 & 2005 & 463,830 \\
\hline 1895 & 26,425 & 2010 & 518,709 \\
\hline 1900 & 31,092 & & \\
\hline
\end{tabular}

to dissolve its own town council and join the city of Durango. In the same time the land was divided for the use of the population of Analco. By 1839, the council of Analco was dissolved and finally became a part of the city of Durango as one of its neighborhoods $\left.{ }^{\mathrm{vi}}\right)($ Fig.2).

4. Understanding the urban formation of Analco and the city plan of 1860

4.1 Urban sprawl changes

The city of Durango and the Indigenous town of Analco have

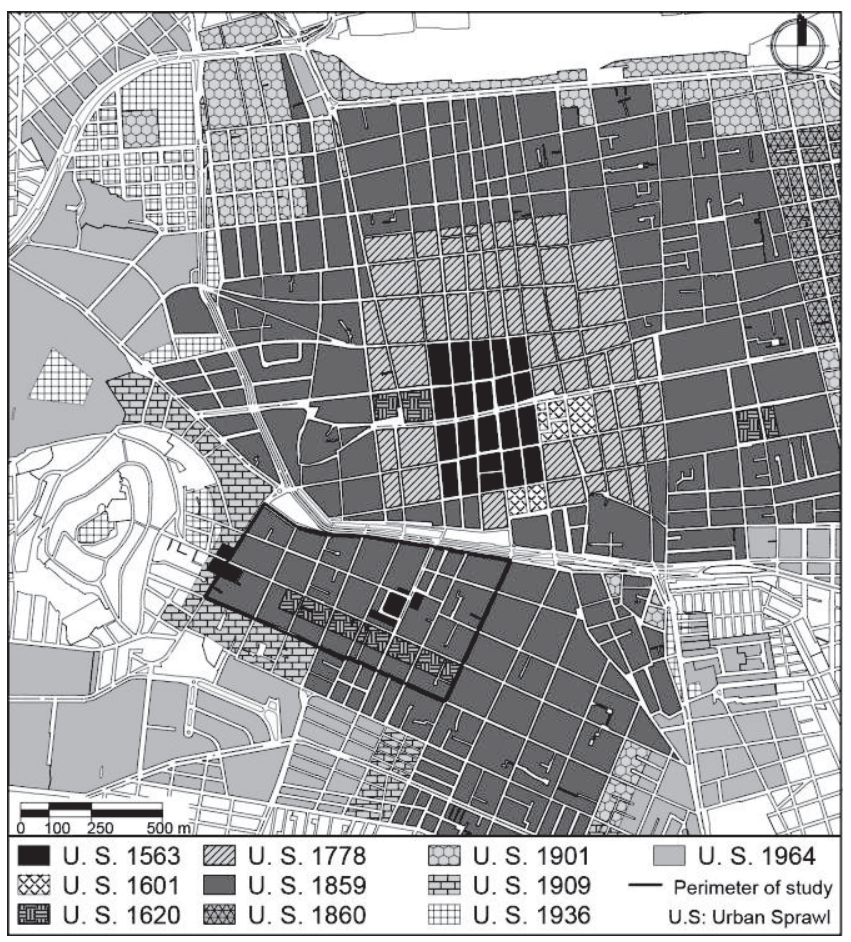

Fig. 3 Changes in Durango's urban sprawl from 1563 to 1964 been depicted on several occasions. Comparing and superimposing several plans of the city from different times spanning from 1563 to 1964 vii) it was possible to know the growth of the city and in particular how the town of Analco came to its current shape, which parts started developing first and the possible reasons for that development (Fig.3). The changes in Durango's growth and urban sprawl, and consequently of Analco, can be related to the changes in its population. The population in 1777 was 6,590 people (Table 1) and the urban sprawl in Fig. 3 shows how such population was distributed in the physical space of the city. By 1859 the roads and blocks were already arranged, however, the periphery blocks were mostly used as agricultural land and did not have a lot of buildings. During the next years, as the population grew, they continued populating the already laid out blocks and it is not until 1901 that another significant growth of the city occurs in the north area; the population at that time was almost double of the one in 1859 but the sprawl did not grow in the same proportion. During the 1930s with a population of 35,330 , the area considered the current HC was developed almost entirely. By 1960 the population was 97,305 and by 1964 the $\mathrm{HC}$ was consolidated, along with further suburban areas.

There is not a lot of literature that deals with the way Analco's urban form was shaped or even how it started. One of the clues of its formation is given by the 1778 urban view of Durango made by Andres Jose de Velasco y Restan (Fig.4). It is evident that Analco's layout was different from Durango's. Analco had a plaza in front of the old chapel, and the government

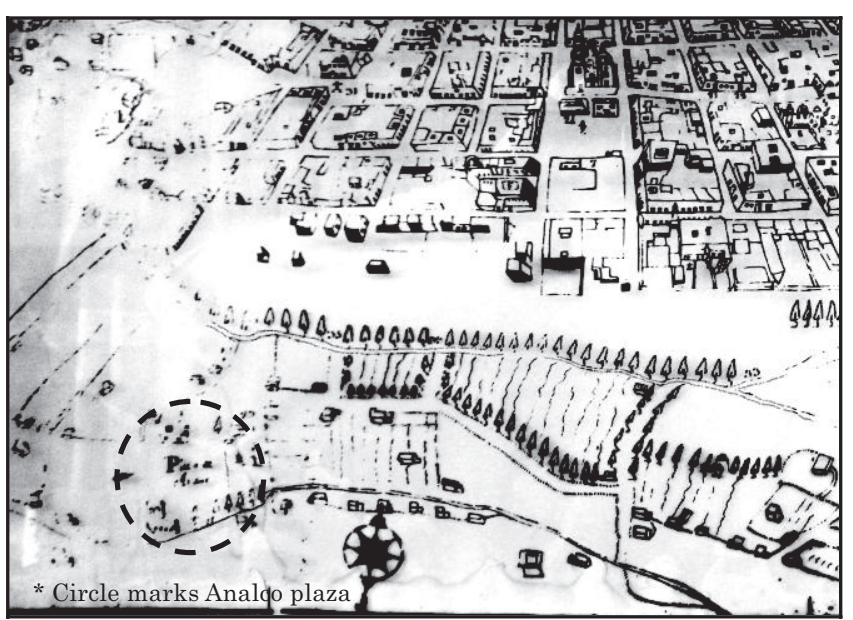

Fig. 4 Detail of the urban view of Durango in $1778^{\text {ix) }}$ 


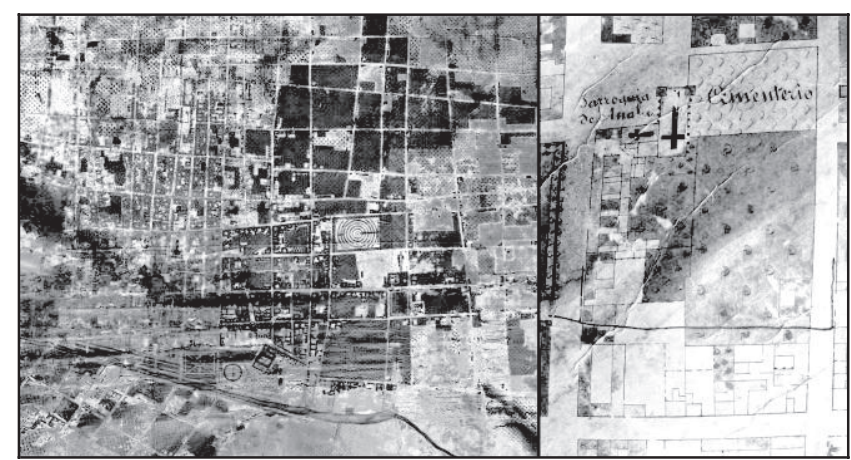

Fig. 5 Left: Durango's urban sprawl in 1860. Right: detail of block 064 of the Analco neighborhood in 1860 $0^{\mathrm{xi}}$

house and other important houses were located around the plaza. The natives were settled in rows of houses that followed the natural slope of the hill in a similar way to other indigenous towns. It is also possible to see a group of houses on one of the sides of Remedios Hill that most probably constitutes a different neighborhood inside the town of Analco ${ }^{8}$.

Another document considered in this study is the 1778 register of Durango. Although the central focus of the register is the city of Durango, there is a small fraction describing the location, dimension, main buildings and population, as well as economic activities of Analco ${ }^{9}$.

\subsection{Blocks in the 1860 plan}

From the different plans showing the urban fabric of the city, the most detailed is the one from 1860, made by Federico Weinder ${ }^{\mathrm{x}}$. Due to its original land registry purpose the plan offers a very good account of the growth of the city at a block level, a detailed depiction of its buildings, and the seven districts the city of Durango had at the time.

Focusing only on the area of Analco (Fig.5), it is possible to notice that the shape of the blocks has not changed in any major way. The layout is more or less in a grid plan, with slight variations on the sizes as well of the shapes of the blocks. The blocks in Analco are double the area of the blocks in the original part of Durango. The four smallest blocks located in front of the church are the product of the division in 1823 of a bigger block to make a street that would allow the church to have a prominent view from the other side of the Acequia Grande Creek ${ }^{\mathrm{vi}}$.

The blocks show the internal divisions and the plots sizes, which in comparison with the current plots sizes are very big, showing that each block had few owners. The land was not divided into equal size plots: some of the blocks have divisions that show very big plots in contrast with some others that are very small.

The plan shows the shapes of the buildings, the empty land, and its uses. Usually the empty spaces closer to the Acequia Grande Creek were used as agricultural land. It is in this part, and also along the streets surrounding the church, where the
Table 2 Prominent buildings in the Analco neighborhood

\begin{tabular}{cl|l|l|l}
\hline & $\begin{array}{c}\text { Founding } \\
\text { year }\end{array}$ & $\begin{array}{l}\text { Previous } \\
\text { use }\end{array}$ & Current use \\
\hline A & $\begin{array}{l}\text { Elementary School } \\
\text { Francisco Zarco } \\
\text { Ice factory and the big } \\
\text { house in the corner } \\
\text { Guadiana La Salle } \\
\text { School }\end{array}$ & $\begin{array}{l}1864 \text { to } \\
1867\end{array}$ & $\begin{array}{l}\text { Education } \\
\text { related }\end{array}$ & $\begin{array}{l}\text { Public school } \\
\text { and offices } \\
\text { Ice factory }\end{array}$ \\
D Elementary School & 1955 & $\begin{array}{l}\text { Private } \\
\text { farm house } \\
\text { Miguel Hidalgo }\end{array}$ & $\begin{array}{l}\text { Catholic private } \\
\text { elementary } \\
\text { school } \\
\text { public } \\
\text { elementary } \\
\text { school } \\
\text { Private school }\end{array}$ \\
E The American School & 1955 & $\begin{array}{l}\text { French } \\
\text { army } \\
\text { barracks }\end{array}$ \\
\hline
\end{tabular}

majority of the buildings are located. On the opposite side of Analco from the Acequia Grande Creek is where we mostly find cactus, maguey and stony grounds.

4.3 Buildings in the 1860 plan

The total area that the buildings occupy in the overall space is considerably smaller than the total vacant area and in fact some of them still have the same shape (although it is not certain whether or not they have the same interior layout and facades as the ones they had in the past).

Most probably the development of the blocks started from the corners, as the blocks with fewer buildings in the plan of 1860 show. In other blocks, even though the central areas are still not completely closed from the exterior, there is a certain tendency to start enclosing them and form the areas that we now call PBIS. The greater concentrations of buildings, located around the church and along Belisario Dominguez Street and Juan E. Garcia Street, give insight to the areas of the neighborhood that started developing first.

Due to the lack of registries, the identification of some of the most prominent buildings in Analco and their times of establishment helped to clarify the subsequent development (Table 2). Locating these buildings in the plan of Analco, it is possible to see towards which direction the development of the neighborhood continued and that little by little the area started gaining more importance. Besides the prominent buildings described in table 2 there are also other landmarks indicated in figure 7. There is written record of another institution, the Methodist Episcopal Church South, which was also established in Analco. However, the exact location of the building is not specified xii).

5. Block transformation, architecture and perimeter block inner spaces

\subsection{Blocks sizes and shapes}

There have been several studies related to colonial cities that attempted to explain the reasons for the sizes of their blocks. Jimenez Verdejo et al. tried to verify the sizes of the blocks of several colonial cities with the measurements specified in the Law of Indies ${ }^{10,11)}$. In fact, the city of Durango does not follow the 


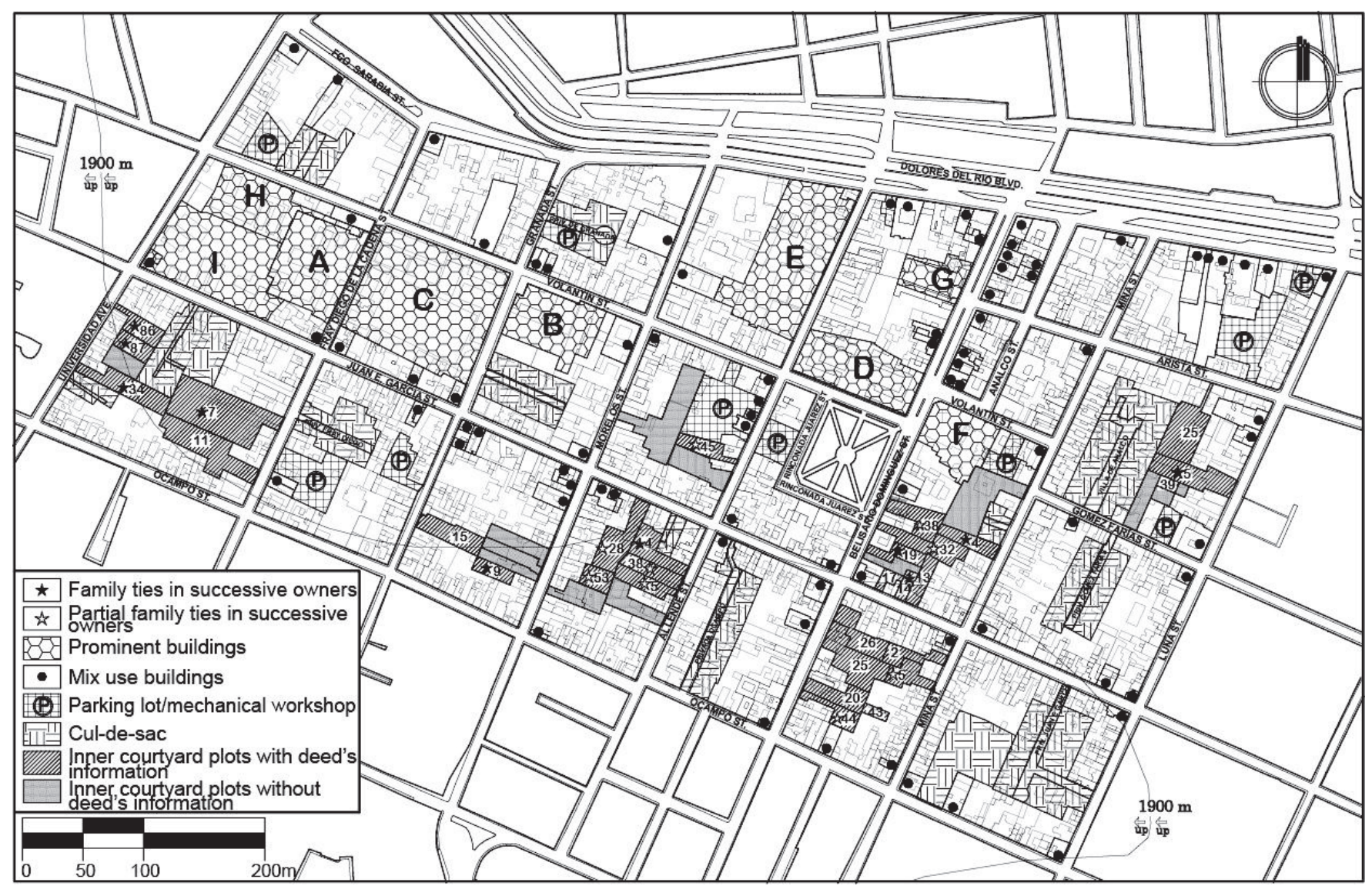

Fig. 6 Perimeter block inner spaces, parking lots and prominent buildings in the Analco neighborhood. Analco's parish (F); the Analco local market (G); the juvenile detention center (H); and the center for intellectually disabled people (I).

measurements of the Law of Indies, but has the common elements described in the document, such as the location of the main square, the church, the city council and the orientation of the streets ${ }^{11,12)}$. The blocks in the area of study are not of regular form, and there are four different shapes: L-shape, trapezium, trapezoid and rectangular, the last two being the more common in the neighborhood. The first intention for the blocks was to make them in a regular grid shape but the irregularities of the land provoked the irregularities in the blocks (Fig.6).

Likewise the dimension of the blocks varies (Table 3). They

Table 3 Dimensions of the blocks of the Analco

\begin{tabular}{|c|c|c|c|c|c|}
\hline $\begin{array}{l}\text { No. of } \\
\text { block }\end{array}$ & $\begin{array}{l}\text { Width } \\
\text { (m) }\end{array}$ & $\begin{array}{l}\text { Length } \\
\text { (m) }\end{array}$ & $\begin{array}{l}\text { No. of } \\
\text { block }\end{array}$ & $\begin{array}{l}\text { Width } \\
\text { (m) }\end{array}$ & $\begin{array}{c}\text { Length } \\
\text { (m) }\end{array}$ \\
\hline 088 & 180 & 137 & 075 & 104 & 128 \\
\hline 056 & 149 & 136 & 065 & 98 & 134 \\
\hline 058 & 145 & 145 & 084 & 116 & 111 \\
\hline 057 & 147 & 123 & 090 & 145 & 72 \\
\hline 073 & 102 & 184 & 081 & 105 & 123 \\
\hline 089 & 163 & 111 & 082 & 105 & 130 \\
\hline 074 & 110 & 162 & 083 & 110 & 90 \\
\hline 064 & 100 & 162 & 071 & 104 & 128 \\
\hline 085 & 119 & 134 & $060 *$ & 55 & 91 \\
\hline 080 & 111 & 141 & $063 *$ & 53 & 82 \\
\hline 059 & 146 & 111 & $061^{*}$ & 36 & 79 \\
\hline 076 & 98 & 140 & $062 *$ & 34 & 70 \\
\hline 070 & 108 & 132 & & & \\
\hline
\end{tabular}

* These 4 small blocks were previously one single block. Width is measured east to west. length. north to south. range from $180 \mathrm{~m}$ to $98 \mathrm{~m}$ in width, and from $184 \mathrm{~m}$ to $72 \mathrm{~m}$ in length. In the majority of the cases, the dimensions of the blocks of the Analco neighborhood are double the size of the majority of the blocks included in the core zone of the HC of Durango (Fig.1). The blocks in Analco and the ones closer to the limits in the rest of the extension of the protected area in the $\mathrm{HC}$ share similar bigger proportions (Fig.1). The relationship between the location of the blocks and their uses show that the bigger blocks had an agricultural usage which is not preserved nowadays. The size of the blocks in Analco is related to its position within the city of Durango (Table 3, Fig. 6).

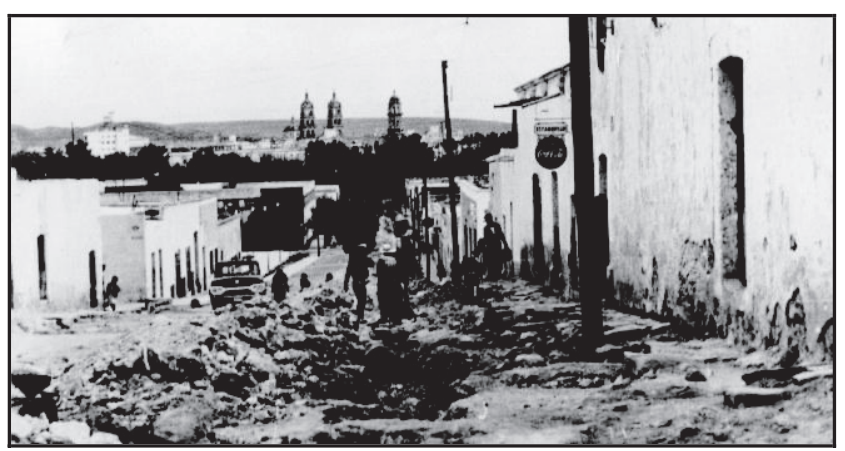

Fig. 7 The Analco neighborhood in the first half of $20^{\text {th }}$ century, most probably taken from Luna Street xiii) 


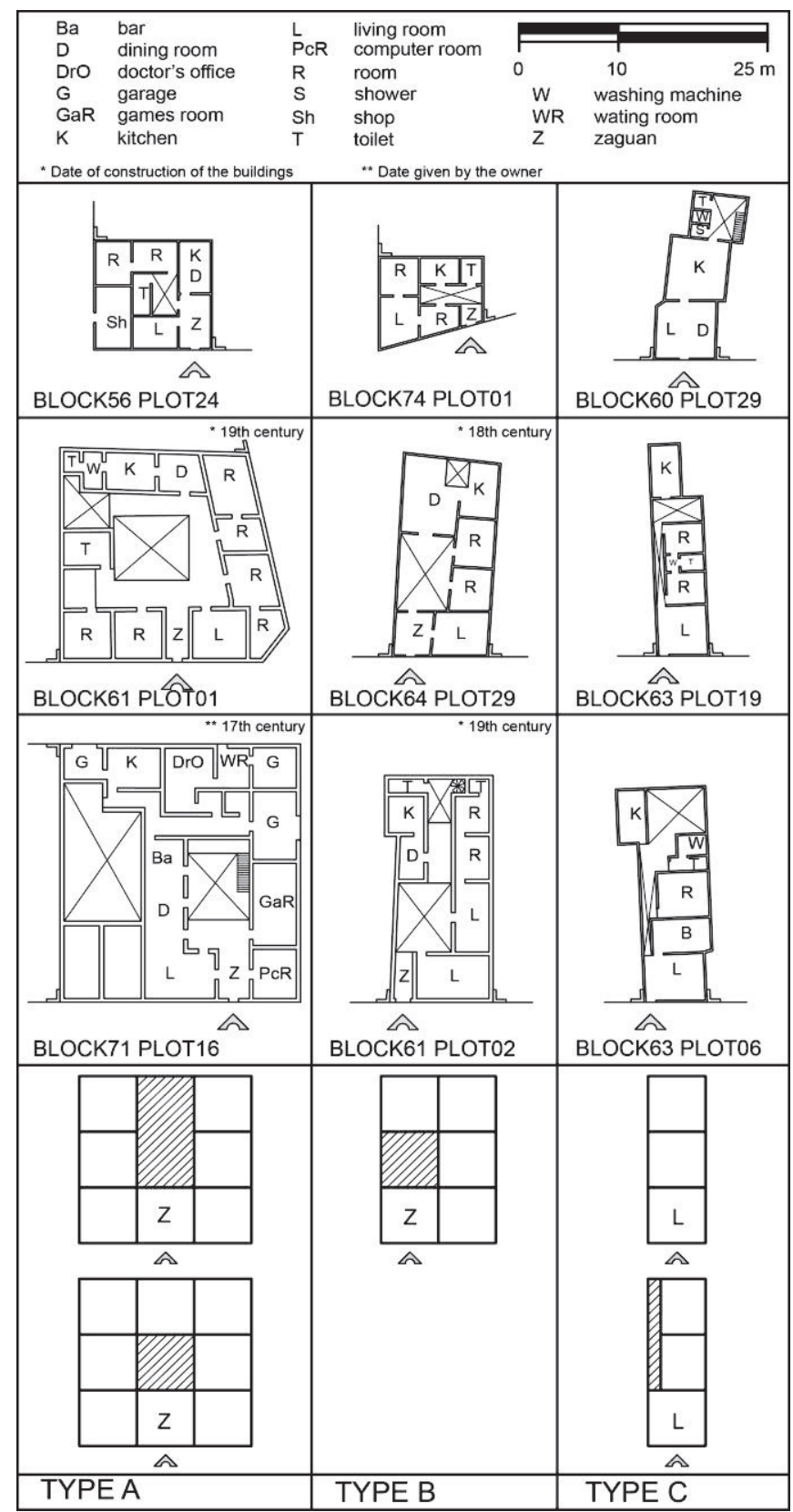

Fig. 8 Patterns of inner layouts of houses in Analco

\subsection{Building pattern}

According to the 1778 registry census, in Durango there were several types of houses, $72 \%$ of them corresponding to low houses made of adobe and smaller houses mainly located in the periphery of the city, at that time the poorest area. These houses most probably are like the ones that appear in some photographs of Analco from the beginning of the $20^{\text {th }}$ century (Fig.7), the houses only having one or two rooms, no windows, two rooms and a separated kitchen. These kinds of houses are still seen very frequently in the countryside. However in the neighborhood they have disappeared completely ${ }^{8)}$.

The houses analyzed are the one constructed after the poorest and smallest houses disappeared. In general, even the newest houses from the cul-de-sacs, correspond to single-family houses and there are no apartment buildings. From the twenty-six houses located in different points of the neighborhood for analysis of the internal layout, there are clearly three major types or patterns (Fig.8):

a) Type A corresponds to the houses on a square plot with the rooms arranged around a central patio. The entrance is made through the "zaguan", or entrance hall, and the living room is always at either side of the zaguan, with direct communication with the street.

b) Type B corresponds to the houses that have clearly a main patio and the rooms are arranged around it, but the plot is not big enough for the patio to become a centerpiece of the layout of the house. The entrance is made through the zaguan, and next to it the living room with direct communication with the street.

c) Type $\mathrm{C}$ corresponds to the houses that are arranged in a long small plot with a series of rooms one after the other. The zaguan has disappeared and the entrance is made directly into the living room. The patio seems more like an independent element of the house.

The obvious common characteristic among the three patterns is the position of the living room in the house, which allows direct connection with the street. The existence of a zaguan is common to Type A and Type B. Type C has no entrance hall, mainly due to the lack of space, and in those cases, the main door connects directly to the living room. Type $\mathrm{C}$ corresponds to a house that is approximately $1 / 3$ of the size of a Type A. The shape of the plot is directly connected to the pattern of the house, although it is not the only factor.

\subsection{Plot division and block typology}

Through the 1860 plan is possible to know that the division of the plots was not made in a regular way and the successive divisions, with the exception of the plots that were used as cul-de-sacs, are also very irregular. The blocks that had less plot divisions in 1860 tend to have a more regular plot division nowadays (Fig.9).

The predominant use of the Analco neighborhood is as living spaces; however there are some houses that have mix use and are spread in the neighborhood mainly along the main streets, near Guadiana School and in the corners of the blocks (Fig.6). Each block has its own dynamic, and this depends on the different spaces located in them and the kind of use the former empty spaces were given. There are a total of four different uses for the previous empty spaces: prominent building, cul-de-sac, parking lot and PBIS. The different combinations of these four uses give a total of twelve different kind of blocks (Table 4), the most complex being the one corresponding to block 064 and the least complex the one corresponding to block 062. Conversely, the other blocks have already used their PBIS to make cul-de-sacs in some cases, parking lots in other cases, or both. Due to their size 


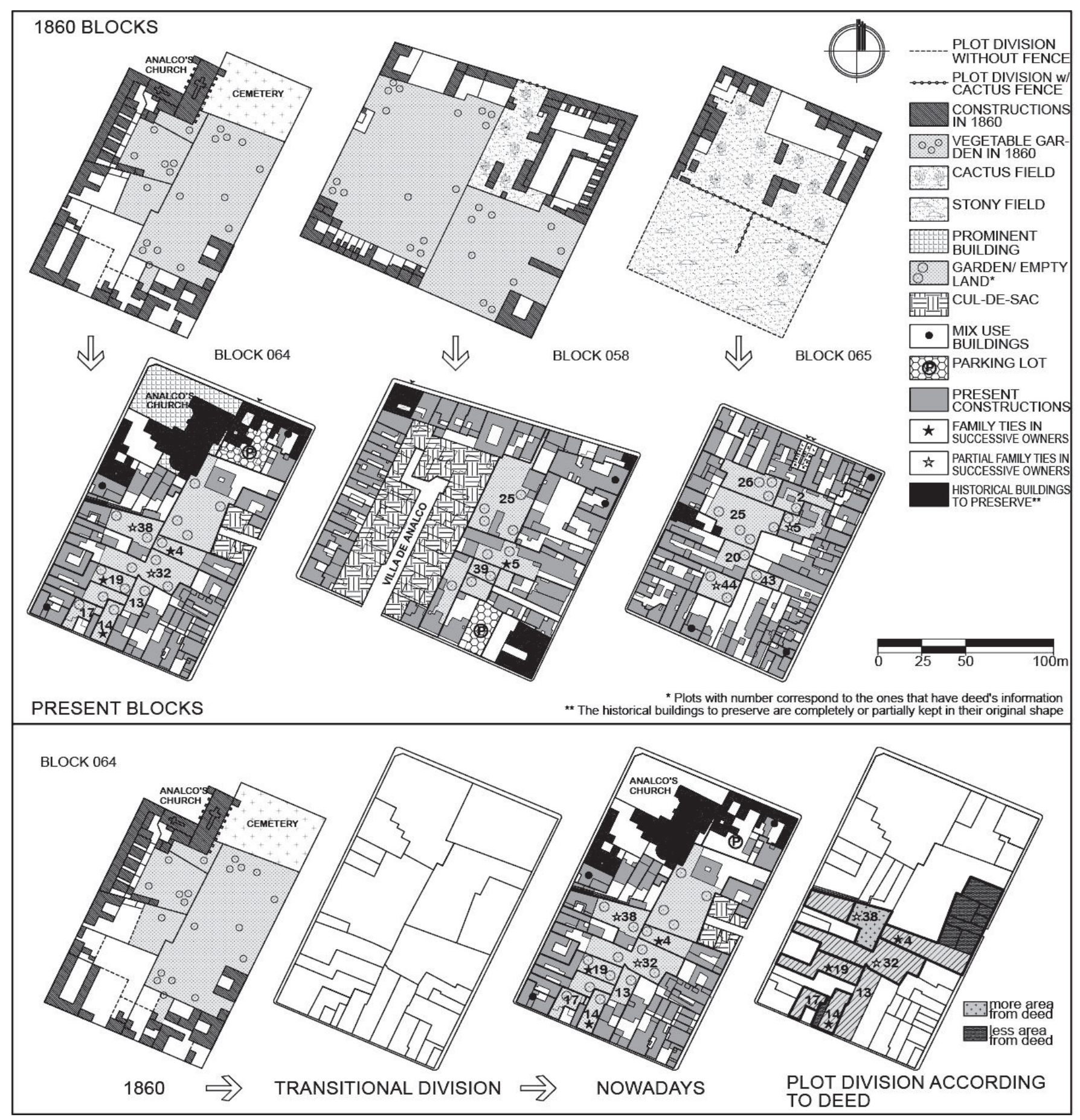

Fig. 9 Upper part: Analco's block transformation from 1860 to the present day. Lower part: diagram of the transformation of plots

the five smallest blocks do not contain the so called PBIS, therefore their dynamics are limited to the default residential or mix use given to the buildings constructed there.

It could be expected the size of the blocks to be directly related to the number of dynamics contained in a certain block, however this is not the case: the biggest block which is 088 (Table 3) contains only a PBIS and a cul-de-sac (Table 4). The second largest block is 056 and it only contains a cul-de-sac. The third largest block is 058 and contains a PBIS, a cul-de-sac and a parking lot. Block 064, which is the block containing all four dynamics is by no means the biggest of the area, but the eight largest; the special building contained in this block is the church, which is a very important building within the neighborhood. The evidence shows that the dynamics of the blocks are more related to their context and location rather than to their sizes.

Among the dynamics occurring in the blocks, the cul-de-sacs and prominent buildings are the most positive uses currently given to the space. It is evident that there is a relationship between the existence of a PBIS and the lack of a prominent building. In addition there seems to be a relationship between 
Table4 Block typology in Analco neighborhood. See (Fig.10)

\begin{tabular}{r|l|l|l|l|l}
\hline Type & No & PB & C & P & B \\
\hline 1 & $064^{*}$ & $\bullet$ & $\bullet$ & $\bullet$ & $\bullet_{\text {Ch }}$ \\
\hline 2 & $058^{* *}$ & $\bullet$ & $\bullet$ & $\bullet$ & \\
\hline 3 & $088^{*}$ & $\bullet$ & $\bullet$ & & \\
& $076^{* *}$ & $\bullet$ & $\bullet$ & & \\
\hline 4 & $085^{* *}$ & & $\bullet$ & $\bullet$ & \\
& $090^{* *}$ & & $\bullet$ & $\bullet$ & \\
\hline 5 & $082^{* *}$ & & $\bullet$ & $\bullet$ & \\
\hline 6 & $075^{* *}$ & $\bullet$ & & $\bullet$ & \\
\hline 7 & $081^{* *}$ & & $\bullet$ & & $\bullet_{\mid}$ \\
\hline 8 & $080^{* *}$ & $\bullet$ & & & \\
\hline 9 & $065^{* *}$ & $\bullet$ & & & \\
\hline 9 & $056^{* *}$ & & $:$ & & \\
& $057^{* *}$ & & $\bullet$ & & \\
\hline 10 & $070^{* *}$ & & $\bullet$ & & \\
\hline & $059^{* *}$ & & & $\bullet$ & \\
& $071^{* *}$ & & & $\bullet$ &
\end{tabular}

\begin{tabular}{c|c|c|c|c|l} 
Typ & No & PB & C & P & B \\
\hline 11 & $073^{*}$ & & & & $\bullet$ S, \\
& $089^{*}$ & & & & $\bullet$ S,J, \\
& $074^{*}$ & & & & $\bullet$ S \\
& $084^{* *}$ & & & & $\bullet$ S \\
\hline 12 & $083^{* *}$ & & & & \\
& 060 & & & & \\
& 063 & & & & \\
& 061 & & & & \\
& 062 & & & & \\
\hline
\end{tabular}

No block number

PB perimeter block inner space

C cul-de-sac

B prominent building

Ch church; I ice factory;

S school; M market; J juvenile center center for disabled people

* Width or length of $150 \mathrm{~m}$ or more

*** Width or length from $150 \mathrm{~m}$ to $100 \mathrm{~m}$

the existence of a PBIS and the existence of a cul-de-sac. In general, the prominent buildings correspond to bigger constructions that sometimes cover the totality of the block's area, with the exception of the block 064. The cul-de-sac does not always correspond to a big development, therefore is possible to find it in the same space as a PBIS.

\subsection{Perimeter block inner spaces}

The buildings that were constructed in Analco, were laid out on the perimeter of the block, and mainly started from its corners. This tendency of placing the houses precisely at the level of the street resulted in the enclosing of the inner area of the blocks. Considering that the sizes of the blocks in Analco are bigger than the ones in central Durango, the remaining PBIS are also of considerable size (Fig.6). Out of the 25 blocks included in the perimeter under investigation, only seven of them have a big PBIS worthy of consideration for introducing a new rehabilitation plan. As the zone corresponds to a residential area the plots that form the totality of the seven PBIS are private property. Even though the shape of the blocks did not have major changes, in relation to the 1860 plan, the plot's division changed. The old division of plots gave rise to the new division, and the PBIS have been made from the amalgamation of the back portion

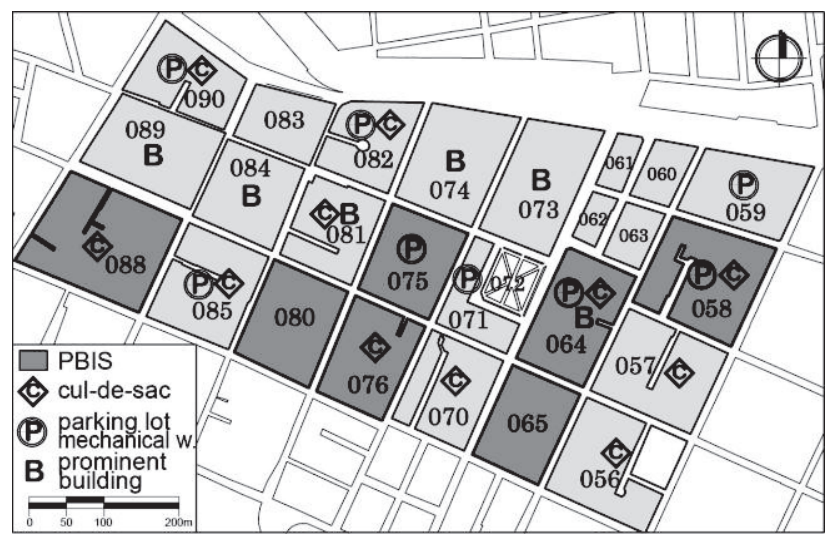

Fig.10 Block typology in the Analco neighborhood. See Table 4

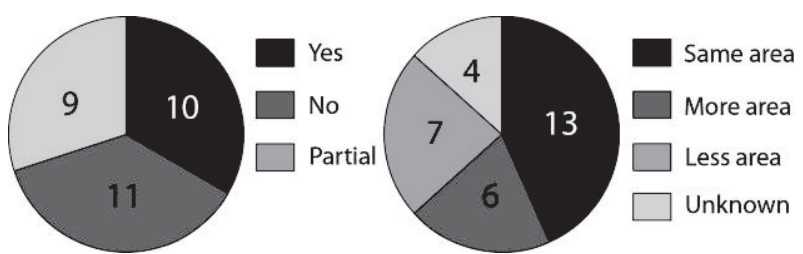

Fig.11 Plot deed's information. Left; family ties. Right: Area in last deed. Numbers represent the number of deeds.

of the larger plots that were not used as cul-de-sacs or parking lots (Fig.9).

In order to know more details about the plots comprising the PBIS, it was possible to get access to the property deeds of some of those plots, some of them as old as from 1914xiv). Through careful examination of the deeds, it was possible to determine that almost two-thirds of the plots with deed's information have had complete or partial family ties among successive owners (Fig.6, Fig. 12). This means that the properties passed down between members of the same family. There are some cases were the property was sold to someone outside the family but was later recovered by some member of the original owner's family. In the majority of the cases involving family ties, the properties were obtained by inheritance and less often by sale or donation.

With respect to the plot's area as shown in the deed, it was found that less than half of the plots' actual areas match with the area of its corresponding deed: in $23 \%$ of the plots, the area is smaller and in $20 \%$ of the plots the actual area is bigger than that described in the corresponding deed. The areas of the remaining $57 \%$ of plots are known, however the information in the deed was not found (Fig.11).

It is not certain why $43 \%$ of the plots have some disparity between their actual area and the area written in the property deeds. One of the possible reasons could be related to the family ties among the owners of the plots. In the case of the plot having less area, most probably they were segmented by the original owners to leave it to more than one heir (Fig.9). Most importantly, the properties remain in the same family. In the opposite case, the excess of area of one plot can be a consequence of invasion, although this information cannot be confirmed by this study.

\section{Conclusions}

\subsection{Facts summary}

The differences in the time of establishment and the main economic activities between Analco and Durango created a different urban fabric that reflected especially in the size of their blocks. The blocks located in the surroundings of Durango and in Analco were used for agricultural and pastureland. In addition the rural area of Analco had blocks that doubled in size the ones from urban Durango. The primary activity of the Indigenous town of Analco was agriculture, activity the natives practiced even before they were conquered by the Spaniards ${ }^{13)}$. By contrast, 
the city of Durango was a city concentrated in its center and its main activity was in the mining industry.

The area of Analco was comprised not only by agricultural land. In the beginning of its foundation, the little development started with the creation of the main plaza and the church, as well as more formally defined indigenous people's houses (see Fig. 3, Analco's urban sprawl in 1563 and 1620). The surroundings of this main portion of the town were dedicated to agriculture. Subsequently, little by little the roads were laid out and by 1823 the block located in the front of the church was segmented. That is the sole major block modification in Analco.

The shape of the blocks of Analco was sometimes influenced by the natural irregularities of the land (Acequia Grande Creek, Remedios Hill and the natural slopes) and the current plot division has traces from the old 1860 plot division. In the majority of the blocks in Analco the width and/or length exceed $100 \mathrm{~m}$. Consequently some of the plots contained in the blocks are longer than usual and the buildings constructed in those plots do not cover the totality of the area of the plot. These blocks are the ones that nowadays have the areas forming the PBIS.

The building's inner layout of the houses is more related to the shape of the plot than to its size. The building types show a transformation of the shape of the plans of the houses, from the square plot of Type A, to the more rectangular shape of Type B, and finally going to the more narrow shape of Type C. There is no space in between the street and the façade of these houses, so it can be inferred that the basic house is one without a front garden.

The blocks dynamics have no relation with the size of the blocks: as it was mentioned before, the block containing the most dynamics is not the biggest one, but one of the blocks located in the oldest part of the neighborhood (block 064). In addition, the biggest block (block 088) contains only PBIS and cul-de-sac. The location and the context of a block have close relationship with the number of dynamics occurring in it. The two blocks containing the most dynamics are located close to each other, in the most prominent area of the neighborhood.

There seems to be a relationship between some of the dynamics occurring in the blocks: a PBIS does not share space with a prominent building. Additionally is more common to find a PBIS and a cul-de-sac in the same block (Table 4). This relationship seems to be influenced by the difference on the scale of a certain prominent building (bigger) and a cul-de-sac (smaller).

The PBIS are the natural result of the oversized blocks, the irregular division of the plots and the different types of buildings arranged along the street with no space in between the pedestrian sidewalk and the façade. These inner spaces were empty land from the beginning and went from agricultural land to private yards, having a variety of positive (i.e. cul-de-sac) and negative (i.e. parking lot) uses.

\subsection{Recommendations}

The lack of public spaces and green areas in Analco could be an important factor to propose the use of the blocks' inner spaces exclusively as gardens. However, the authors think that the regeneration strategy to follow should be influenced by the local needs of the area according to the location of the blocks within the neighborhood, the size of their perimeter block inner spaces and their particular urban context. Considering the area is a buffer zone, it should be advisable to find a feasible way to connect the inner spaces with the exterior, protecting the historical buildings to preserve in each block (Fig.9) and observing the restrictions applied by the codes for protection of the historical areas in the city5).

Trying to emulate successful cases like the one from Barcelona ${ }^{14)}$, giving uses to the inner spaces of not only green areas, but also of public facilities such as nursery schools and markets, among other uses ${ }^{\mathrm{xv}}$, the ideal regeneration through the PBIS in Analco should include a particular plan for the use of each space. For instance, the smaller spaces of the blocks 080 and 058 as urban parks; the medium space of block 075 as urban park and commercial space; the medium spaces of block 076 and block 065 as urban infill housing with green areas; the bigger space of block 064, with more dynamics, would be the ideal place for a community center, which is a public space that is needed in the neighborhood, and also an urban infill housing with green areas; last, the biggest space of block 088, closer to more schools, can benefit from a public library and an urban infill housing with green areas.

Another method for the regeneration of the area could be the division of the blocks containing PBIS. This would create blocks around the same size as the ones in the Core Zone of the $\mathrm{HC}$ and would give opportunity for the complete use of the interior of the block as a residential area. It would also be advisable to introduce participatory design as a tool to involve the population along with the developers in the planning process, with the creation of a neighborhood committee for adequate support.

The different proposals would allow the people to use the space in a clever way and would give them a comfortable open space, avoiding the problem of gentrification faced during the rehabilitation of other Mexican colonial cities ${ }^{15}$. It would also give balance to the area, by giving to the PBIS different uses and increasing their blocks' dynamics.

With the passage of time, the existence of family ties among the owners of the plots which created the cul-de-sacs could be of importance, in a sense that deep-rooted ownership would create a strong desire for the rehabilitation of their neighborhood. However, the fact that each individual plot is owned by a different person could be a serious barrier for the rationalization in the use of the PBIS. It is imperative to obtain an agreement 
from all the implicated parts for the appropriate development of the area.

Analco's importance as a buffer zone is not only limited for being a zone of transition and communication between the core zone and the modern areas of the city ${ }^{16)}$ but also for being a historical suburban area. It is essential to preserve the existing living spaces rather than waiting for the buildings to fall down by themselves and then regenerate the remaining space as a way of making the area more sustainable and compact.

\section{References}

1) Coulumb, Rene: Construyendo utopías desde el centro, Habitat popular en los centros antiguos de Iberoamérica CYTED / CENVI Mexico, pp.16-28, 2007

2) García Espinoza, Salvador: Centros históricos ¿herencia del pasado o construcción del presente? Agentes detonadores de un nuevo esquema de ciudad, Scripta Nova. Revista electrónica de geografía y ciencias sociales. Universidad de Barcelona, Vol. 9, No.194 (39), 2005.8, http://www.ub.edu/geocrit/sn/sn-194-39.htm, access date 2011.4.4

3) Ocampo Garcia, Ma. De Lourdes et al.: La pérdida del patrimonio habitacional en el centro histórico de Chiapa de Corzo,Chiapas, Ciencia y tecnología en la frontera. Mexico, Year 2, Vol.2, pp.43-53, 2005.1

4) Angelo, Odicea et al.: Residential Environment of Historic Urban Centre and Conventillo of la Paz, Bolivia, 日本建築学会計画系論文集, No.604, pp. 93-100, 2006. 6

5) Durango City Council: Code for the Historical Centre of the city of Victoria de Durango, Municipal Gazette, Vol.26, No.212, 2009.1

6) Saravia, Atanasio. G.: Obras I Apuntes para la Historia de la Nueva Vizcaya, Universidad Nacional Autonoma de Mexico, 1993.3

7) Law of Indies, the: Book 4, tittle 7, laws 12, 1573

8) Vallebueno Garcinava, Miguel Felipe de Jesus: Civitas y urbs. La conformación del espacio urbano de Durango, Instituto de Investigaciones Históricas de la Universidad Juarez del Estado de Durango, 2006.2

9) Saravia, Atanasio. G.: Obras IV Apuntes para la Historia de la Nueva Vizcaya, Universidad Nacional Autonoma de Mexico, 1993.3

10) Law of Indies, the: Book 4, tittle 7, laws 8 and 10, 1573

11) Jimenez Vardejo J.R. et al.: Considerations concerning measurements relating to the urban design of the Spanish-American city, Journal of Asian Architecture and Building Engineering, Vol.6, No.1, pp.9-16, 2007.5

12) Benevolo, Leonardo: The History of the City, The MIT Press, 1981

13) Swann, Michael M.: Tierra Adentro settlement and society in colonial Durango, Westview Press, 1982

14) Abe, Daisuke: Planning Instruments in Urban Rehabilitation at the Eixample of Barcelona, Journal of Housing Research Foundation, No.36, pp.119-130, 2009

15) Jones, G.A. et al.: The reconquest of the historic centre. Urban conservation and gentrification in Puebla, Mexico, Environment and planning A, Vol.31, pp.1547-1566, 1999

16) WHC: Operational guidelines for the implementation of the World Heritage Convention, United Nations Educational, Scientific and Cultural Organization, 2008.11, http://whc.unesco.org/en/guidelines, access date 2011.5 .9

Notes

i) United Nations Educational, Scientific and Cultural Organization http://whc.unesco.org/en/list/1351, access date 2010.12.20

ii) Office of Property and Public Records in the city of Durango and National Institute of Archaeology and History iii) Federal Act for the protection of Historical Monuments, 1982

iv) INEGI, National Census of Population and Housing

v) The laws of Indies, http://www.congreso.gob.pe/ntley/LeyIndiaP.htm, access date 2011.1.21

vi) Torres Vargas, Benjamin: Analco de pueblo de indios a barrio de la ciudad de Durango, Bitacora de conservación obtained at Analco Parish vii) Municipal Archive of the city of Durango

viii) ITAM Instituto Tecnologico Autonomo de Mexico Virtual Library, biblioteca.itam.mx/docs/ehm/1.3.9.xls, access date 2011.9.13

ix) The original plan is currently exhibited at the Regional Museum of the city of Durango

x) The original is exhibited at the José Ignacio Gallegos Caballero library, in the city of Durango

xi) Detail of the 1860 plan

xii) Elliot Roberto C. Rev.: Actas de las Conferencias Trimestrales, p.20, 1892-1898.

xiii) Photographic library of the INAH. National Institute of Archaeology and History

xiv) Office of Property and Public Records in the city of Durango,

Consulted in April of 2011. In total thirty deeds were consulted

xv) ProEixample, http://www.proeixample.cat/eng/, access date 2011.8.15

\section{和文要約}

アナルコ地区は、メキシコの世界遺産「銀街道」の拠点都市・ドゥ ランゴの中心市街地のすぐ外側に形成された歴史的郊外である。世 界遺産の登録にあたってはバッファゾーンに位置づけられ、メキシ コの歴史的記念物保護法では保存地区に指定されている。しかし、 多くの投資がなされ修復が進んだ中心市街地に対し、アナルコ地区 ほとんど放置され、人口が減り、建物の痛みも激しくなっている。 本論文は、このような地区の衰退の原因と再生の手がかりが街区内 に残された空地にあると考え、アナルコ地区の街区の形成過程を明 らかにしようとした。アナルコ地区は、インディオの独立した集落 としてスタートし、19 世紀にドゥランゴ市に併合された。論文では、 市街化が始まりはじめた 1860 年に作成された、建物の形まで分か る詳細な地図をもとに、その後の変化を街区ごとに検討した。ドウ ランゴ市の街路構成は全体としてグリッドパターンであるが、アナ ルコ地区の街区は一辺が概ね 100～150m の四角形をなし、大部分 が農地として使われていた。一方、住宅は間口に応じて 3 類型が見 出され、いずれも中庭型で、隣と街路に接しており、奥行は $15 \sim 25 \mathrm{~m}$ である。こうして、市街化した後も、ブロックの中に、大きな空地 が残ることとなった。街区によっては大きな施設 (教育機関が多い) が進出したり、クルドサックを設けた住宅地開発が行われたが、そ れ以外の部分では、街区内に空地がのこり、今日では農耕も行われ ていない。こうして、街区の一辺がアナルコ地区の半分で、土地が 余すことなく使われていった中心部との違いが明らかになった。な お、アナルコ地区でも、広場の周辺の街区は奥行が小さく、教会前 面の街区は半分に割られた経過がある。このように、アナルコの衰 退のひとつの原因は、その街区の形態にあると考えられ、その再生 には、これら街区内空地を積極的に活用する方策がとられるべきと いう仮説が成立することが分かった。

(2011年10月 7 日原稿受理，2012年 5 月24日採用決定） 